TERSEDIA SECARA ONLINE

http://journal.um.ac.id/index.php/

pendidikan-geografi/index
JURNAL PENDIDIKAN GEOGRAFI:

Kajian, Teori, dan Praktek dalam Bidang

Pendidikan dan Ilmu Geografi

Tahun 21, No. 2, Juni 2016

Halaman: 131-144

\title{
ANALISIS INDEKS KUALITAS TANAH ANDISOL PADA BERBAGAI PENGGUNAAN LAHAN DI DESA SUMBER BRANTAS KOTA BATU
}

\author{
Juarti $^{1}$
}

\section{Email: juarti.fis@um.ac.id}

\begin{abstract}
Abstrak: Kualitas tanah adalah kapasitas tanah yang berfungsi mempertahankan produktivitas tanaman, mempertahankan dan menjaga ketersediaan air serta mendukung kegiatan manusia. Kualitas tanah yang baik akan mendukung kerja fungsi tanah sebagai media pertumbuhan tanaman, mengatur dan membagi aliran air dan menyangga lingkungan yang baik pula. Penelitian ini dimaksudkan untuk mengetahui indeks kualitas tanah Andisol pada berbagai penggunaan lahan di Desa Sumber brantas kota Batu. Indikator kualitas tanah adalah sifat, karakteristik atau proses fisika, kimia dan biologi tanah yang dapat menggambarkan kondisi tanah. Penelitian ini dilaksanakan di Desa Sumberbrantas Kota Batu dengan order tanah Andisol pada penggunaan lahan monokultur dan tumpang sari. Indeks kualitas tanah dihitung dengan menggunakan kriteria Mausbach dan Seybold (1998), yang dapat disesuaikan dengan kondisi lapangan menggunakan analisis Minimum Data Set (MDS). Berdasarkah hasil penelitian didapatkan Indeks Kualitas Tanah (IKT) lahan monokultur sebesar 0,42 termasuk kriteria sedang, lahan tumpangsari Indeks Kualitas Tanah sebesar 0,38 termasuk kriteria rendah. Nilai indeks kualitas tanah berkisar antara 0-1, semakin nilai indeks mendekati 1 menunjukkan kualitas semakin baik. Tanah yang berkualitas baik akan menjamin keberlanjutan fungsi tanah, baik fungsi produksi maupun fungsi ekologi. Penentuan Indeks Kualitas tanah suatu lahan akan berguna untuk penyusunan arah pengelolaan lahan yang berkelanjutan.
\end{abstract}

Kata Kunci: indeks kualitas, tanah Andisol, penggunaan lahan

\section{PENDAHULUAN}

Komponen tanah yang terdiri dari bahan padatan, air dan udara merupakan sumberdaya alam utama yang sangat memengaruhi kehidupan. Tanah mempunyai fungsi utama sebagai tempat tumbuh dan berproduksi tanaman. Kemampuan tanah sebagai media tumbuh akan optimal jika didukung oleh sifat fisika, kimia dan biologi yang baik, biasanya menunjukkan tingkat kesuburan tanah (Sartohadi, dkk., 2012)

Kesuburan tanah yang tinggi menunjukkan kualitas tanah yang tinggi. Kuali-

${ }^{1}$ Dosen Jurusan Geografi FIS UM tas tanah adalah kapasitas tanah yang berfungsi mempertahankan produktivitas tanaman, mempertahankan dan menjaga ketersediaan air serta mendukung kegiatan manusia. Kualitas tanah yang baik akan mendukung kerja fungsi tanah sebagai media pertumbuhan tanaman, mengatur dan membagi aliran air dan menyangga lingkungan yang baik pula (Winarso, 2005).

Kualitas tanah yang terjaga akan berpengaruh kepada manusia secara ekonomi dengan penjualan hasil panen, ketahanan tanah terhadap erosi, 
kesehatan manusi yang terminimalisasi dari pengaruh logam berat ataupun sebagai konsumen dari hasil panen yang di peroleh. Kualitas tanah sangat erat hubungannya dengan lingkungan, yaitu tanah tidak hanya dipandang sebagai produk transformasi mineral, bahan organik dan sebagai media pertumbuhan tanaman tingkat tinggi, tetapi dipandang secara menyeluruh, yaitu mencakup fungsifungsi lingkungan dan kesehatan.

Menurunnya kemampuan tanah dalam melaksanakan fungsi-fungsinya menunjukkan telah terganggunya kualitas tanah yang mengakibatkan bertambahnya lahan kritis, penurunan produktivitas tanah dan pencemaran lingkungan. Salah satu penyebab penurunan kualitas tanah adalah perubahan penggunaan lahan atau konversi lahan (Arifin, 2011).

Jumlah penduduk yang meningkat menyebabkan kebutuhan manusia akan pangan dari tahun ke tahun semakin meningkat. Selain dengan teknik intensifikasi, usaha untuk meningkatkan produksi di lakukan dengan cara ekstensifikasi atau perluasan areal tanam. Perluasan areal tanam mengharuskan membuka areal hutan atau padang rumput yang semula merupakan daerah konservasi menjadi lahan pertanian baru. Konversi hutan menjadi lahan pertanian menyebabkan penurunan kualitas tanah. Hal ini disebabkan oleh: (1) lahan menjadi semakin terbuka, sehingga erosi permukaan akan semakin tinggi, (2) intensitas penanaman yang tinggi akan menguras banyak unsur hara dan bahan organik tanah, dan (3) penggunaan pestisida dan bahan kimia lainnya akan mencemari lingkungan (Utomo, 1994).

Kualitas tanah diukur berdasarkan pengamatan kondisi dinamis indikatorindikator kualitas tanah. Pengukuran indikator kualitas tanah menghasilkan indeks kualitas tanah. Indeks kualitas tanah merupakan indeks yang dihitung berdasarkan nilai dan bobot tiap indikator kualitas tanah. Indikator-indikator kualitas tanah dipilih dari sifat-sifat yang menunjukkan kapasitas fungsi tanah (Partoyo, 2005).

Indikator kualitas tanah adalah sifat, karakteristik atau proses fisika, kimia dan biologi tanah yang dapat menggambarkan kondisi tanah. Menurut Doran \& Parkin (1994), indikator-indikator kualitas tanah harus (1) menunjukkan proses-proses yang terjadi dalam ekosistem, (2) memadukan sifat fisika tanah, kimia tanah dan proses biologi tanah, (3) dapat diterima oleh banyak pengguna dan dapat diterapkan di berbagai kondisi lahan, (4) peka terhadap berbagai keragaman pengelolaan tanah dan perubahan iklim, dan (5) apabila mungkin, sifat tersebut merupakan komponen yang biasa diamati pada data dasar tanah. 


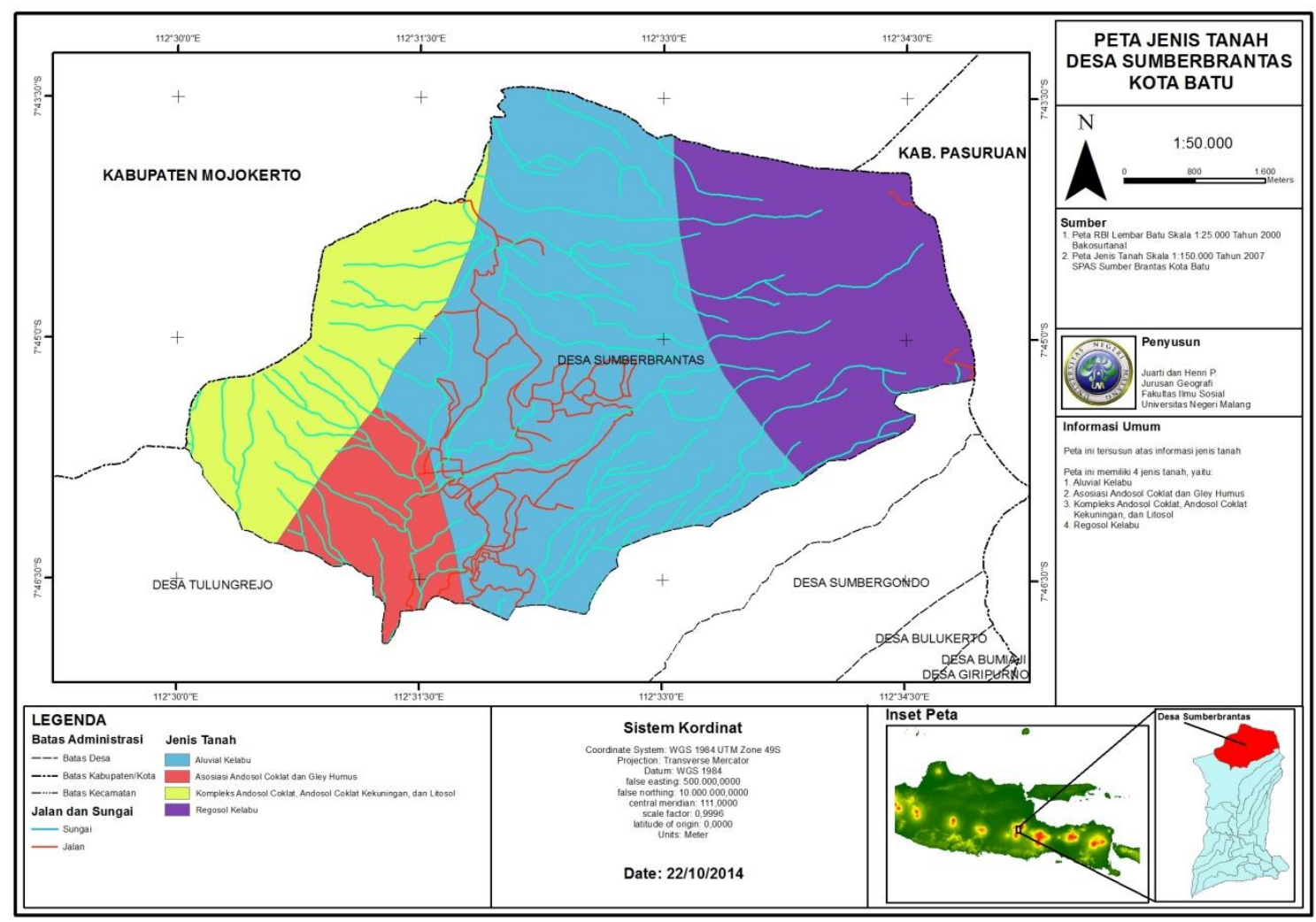

Gambar 1. Peta Jenis Tanah Daerah Penelitian

Desa Sumber Brantas merupakan desa yang terletak di wilayah barat daya lereng gunung Arjuno yang merupakan daerah pegunungan dan mempunyai hamparan lahan pertanian yang memberikan kesejahteraan bagi masyarakatnya. Penduduk desa Sumber Brantas berjumlah 3872 jiwa, sekitar 60\% adalah petani dan merupakan sentra penghasil sayur mayur, memiliki kelerengan dari miring sampai curam yang sangat berpotensi untuk terjadinya erosi ditambah dengan penggunaan lahan yang intensif. Disamping itu karena adanya alih guna lahan dari hutan menjadi lahan pertanian sayur-sayuran. Sehingga, berdampak pada terjadinya degradasi lahan dan menurunnya kualitas serta kuantitas air (Anonimous, 2011).

Jenis tanah di desa Sumber Brantas didominasi oleh tanah Andosol (order
Andisol). Tanah order Andisol merupakan tanah yang berkembang dari bahan induk tuf vulkanik dan abu vulkanik yang relatif masih muda. Topografi bergelombang, agak rata dan dataran tinggi gunung berapi, di bawah vegetasi hutan tropika basah. Merupakan tanah yang masih muda, sehingga proses-proses pembentukan tanah masih lemah (Handayanto,1983).

Solum Andisol umumnya agak dalam sampai dalam, mempunyai horison $\mathrm{A}$ umbrik tetapi horison B yang baru berkembang. Struktur tanah umumnya remah, konsistensi tanah gembur. Tekstur tanah dicirikan oleh kandungan debu yang tinggi. Reaksi tanah rendah sekitar $0.8 \mathrm{gr} / \mathrm{cm} 3$, kejenuhan basa sedang, fiksasi $\mathrm{P}$ tinggi, kapasitas tukar kation rendah, kandungan unsur hara rendah, terutama N, P dan K. Permeabilitas baik, 
tetapi sangat peka terhadap erosi (Sartohadi, dkk, 2012).

Penggunaan Andisol untuk lahan pertanian seperti tanaman sayuran akan semakin menguras ketersediaan unsur hara dan bahan organik tanah jika pengelolaan lahan tidak memperhatikan tehnik-tehnik konservasi. Hal ini menyebabkan penurunan kualitas tanah.

Sejak tahun 2000 produktivitas pertanian di Desa Sumber Brantas menurun, penyebabnya kondisi tanah mulai kurang subur. Berdasarkan data Gapoktan Sumber Jaya terjadi penurunan produksi tanaman sayuran terutama kentang, wortel, kubis, sledri, bawang merah, dan sawi putih, sehingga pendapatan petani kurang maksimal (Jawa Pos, Oktober 2014).

Penurunan produktivitas pertanian disebabkan oleh petani yang kurang memperdulikan kondisi tanah. Penggunaan pupuk anorganik yang berlebih dan pengolahan lahan yang tidak sesuai dengan kaidah konservasi akan memperburuk kondisi kerusakan lahan. Kemiringan lereng yang curam tidak diimbangi dengan pembuatan terasiring sehingga tanah lapisan atas banyak yang hilang akibat erosi. Akibatnya terjadi pemiskinan unsur hara yang dibutuhkan untuk pertumbuhan tanaman.

Berdasarkan hasil survei di lapangan, mayoritas sistem penggunaan lahan di desa Sumberbrantas berupa kebun dengan pola tanaman kentang monokultur, kebun dengan pola campuran tanaman cabe merah,dan bronkoli. Adanya perbedaan sistem penggunaan lahan di desa tersebut diduga akan berpengaruh terhadap pengelolaan lahan, guguran seresah, kualitas seresah, kandungan bahan or- ganik tanah (BOT) sehingga dapat menurunkan kualitas tanah.

Sistem penggunaan lahan dengan pola pohon monokultur maupun pohon campuran akan menimbulkan berbagai interaksi antar tanaman, yang dalam jangka pendek ditekankan pada pengaruh terhadap produksi tanaman semusim. Interaksi positif dari guguran seresah berbagai tanaman ke tanah berguna sebagai penutup permukaan tanah, sehingga dapat meningkatkan laju infiltrasi tanah serta dapat meningkatkan penyediaan unsur hara lain yang berguna untuk tanaman semusim.

Penanaman secara monokultur dan berlangsung secara terus menerus sepanjang tahun dapat menurunkan kesuburan tanah, yang pada akhirnya menyebabkan penurunan hasil. Penanaman ubikayu monokultur dapat menurunkan C-organik (bahan organik), N, K, Mg tersedia, KPK, $\mathrm{pH}$ tanah, stabilitas agregat, kemampuan memegang air dan meningkatkan berat volume. Penanaman tumpangsari atau tumpang gilir dengan berbagai macam tanaman dalam satu petak dapat mengurangi penurunan kesuburan tanah.

\section{METODE}

Penelitian ini menggunakan metode survei. Subyek penelitian adalah Desa Sumberbrantas dengan luas 1346 ha, berdasarkan peta tanah Bakosurtanal (1999) order tanah di Desa Sumberbrantas adalah order Andisol. Andisol yang berkembang dari bahan induk abu vulkanik atau hasil keluaran gunung api yang lain. Iklim di lokasi ini bersifat udic (dengan bulan kering 1-3 bulan) sehingga great group tanahnya adalah Hapludands. Tanah tidak mengalami kekeringan selama 90 hari, 
distribusi curah hujan yang merata dan cukup selama musim tanam. Terjadi pencucian sepanjang tahun.

Penelitian dilakukan dengan melakukan survei lapangan, pengambilan sampel tanah dan analisis di laboratorium. Pengambilan contoh tanah dilakukan secara komposit dari lapisan olah (pada kedalaman 0-25 cm ) dari areal tanaman tumpang sari dan monokultur. Contoh tanah dikering anginkan selama satu minggu kemudian ditumbuk dan diayak menggunakan ayakan dengan diameter lubang $2 \mathrm{~mm}$ untuk keperluan analisis.

Analisis tanah di laboratorium diperlukan untuk mengetahui sifat-sifat fisika dan kimia tanah, meliputi: Kadar lengas tanah dan kadar lengas kapasitas lapangan dengan metode gravimetris, Berat Volume (BV) tanah dengan metode ring sampel, Berat Jenis (BJ) dengan prisip hukum Archimedes, Tekstur tanah dengan metode pipet, Porositas dihitung dengan rumus (1-BI/BJ)x100\%, Pengukuran $\mathrm{pH} \mathrm{H} 2 \mathrm{O}$ dan $\mathrm{pH} \mathrm{KCl}$ dengan $\mathrm{pH}$ meter, $\mathrm{P}$ tersedia tanah dengan metode Bray I, Kalium tersedia tanah dengan pengekstrak 0,1 N NH4Oac pada $\mathrm{pH} \mathrm{7,}$ Nitrogen total dengan metode Kjedal (destruksi dan destilasi), C-organik tanah dengan ekstraksi K2Cr2O7, Penentuan $\mathrm{C} / \mathrm{N}$ ratio menggunakan perbandingan $\mathrm{C}$ organik tanah dan $\mathrm{N}$ total, kedalaman perakaran (kedalaman efektif) dengan mengukur profil tanah.

Berdasarkan data sifat fisik dan kimia di atas, Indeks kualitas tanah dihitung berdasarkan kriteria Mausbach dan Seybold (1998), yang dapat disesuaikan dengan kondisi lapangan menggunakan analisis Minimum Data Set (MDS). Peru- bahan yang dilakukan pada beberapa hal, yaitu:

1. Indikator kemantapan agregat didekati dengan presentase debu+lempung. Presentase debu+lempung sangat menentukan kemantapan agregat yang dapat berperan pada fungsi pengaturan kelengasan, penyaring dan penyangga tanah.

2. Indikator $\mathrm{C}$ total dapat diganti dengan $\mathrm{C}$ organik, dengan pertimbangan bahwa pengukuran $\mathrm{C}$ organik lebih mudah dilakukan.

3. Batas atas dan batas bawah beberapa indikator tanah diturunkan atau dinaikkan, disesuaikan dengan hasil pengukuran parameter di lapangan.

Modifikasi tersebut terangkum dalam Tabel 1 pada halaman berikutnya.

Cara perhitungan indeks adalah sebagai berikut :

A. Indeks bobot dihitung dengan mengalikan bobot fungsi tanah (bobot 1) dengan bobot medium perakaran (bobot 2) dengan bobot jeluk perakaran (bobot 3). Misalnya, indeks bobot untuk porositas diperoleh dengan mengalikan 0,40 (bobot 1) dengan 0,33 (bobot 2) dengan 0,60 (bobot 3), dan hasilnya sama dengan 0,080 .

B. Skor dihitung dengan membandingkan data pengamatan dari indikator tanah dan fungsi penilaian. Skor berkisar dari 0 untuk kondisi buruk dan 1 untuk kondisi baik. Penetapan skor dapat melalui interpolasi atau persamaan linier sesuai dengan kisaran yang ditetapkan berdasar harkat atau berdasarkan data yang diperoleh.

C. Indeks kualitas tanah dihitung dengan mengalikan indeks bobot dan skor dari indikator. 
136

Juarti. Analisis Indeks Kualitas Tanah Andisol Pada Berbagai Penggunaan Lahan di Desa Sumber Brantas Kota Batu

Tabel 1. Modifikasi Indikator, Bobot dan Batas-batas Fungsi Penilaian

\begin{tabular}{|c|c|c|c|c|c|}
\hline Fungsi Tanah & Bobot I & Indikator Tanah & Bobot II & Bobot III & $\begin{array}{l}\text { Indeks } \\
\text { Bobot }\end{array}$ \\
\hline Melestarikan aktivitas biologi & 0,4 & Medium perakaran & 0,30 & & \\
\hline & & Jeluk perakaran $\mathrm{cm}$ & & 0,6 & 0,07 \\
\hline & & Berat Volume gr/cm3 & & 0,4 & 0,048 \\
\hline & & Kelengasan & 0,30 & & \\
\hline & & Porositas \% & & 0,2 & 0,024 \\
\hline & & C-Organik \% & & 0,4 & 0,048 \\
\hline & & Debu + Lempung \% & & 0,4 & 0,048 \\
\hline & & Keharaan & 0,30 & & \\
\hline & & $\mathrm{pH}$ & & 0,1 & 0,012 \\
\hline & & P tds ppm & & 0,2 & 0,024 \\
\hline & & $\mathrm{K}$ tds me $/ 100 \mathrm{~g}$ & & 0,2 & 0,024 \\
\hline & & $\mathrm{C}-$ organik $\%$ & & 0,3 & 0,036 \\
\hline & & $\mathrm{N}-$ tot $\%$ & & 0,2 & 0,024 \\
\hline \multirow[t]{3}{*}{ Pengaturan dan penyaluran air } & \multirow[t]{3}{*}{0,3} & Debu + Lempung \% & 0,60 & & 0,180 \\
\hline & & Porositas \% & 0,20 & & 0,060 \\
\hline & & Berat Volume g/cm3 & 0,20 & & 0,060 \\
\hline \multirow[t]{5}{*}{ Filter dan buffering } & \multirow[t]{5}{*}{0,3} & Debu + Lempung \% & 0,60 & & 0,180 \\
\hline & & Porositas \% & 0,10 & & 0,030 \\
\hline & & Proses mikrobiologis & 0,30 & & \\
\hline & & $\mathrm{C}-$ organik $\%$ & & 0,5 & 0,045 \\
\hline & & Bahan Organik \% & & 0,5 & 0,045 \\
\hline Total & & & & & 1,0 \\
\hline
\end{tabular}

HASIL PENELITIAN

Berdasarkan hasil analisa sifat fisika tanah,kimia tanah dan kedalaman perakaran pada penggunaan lahan monokul- tur dan tumpangsari disajikan pada tabel di bawah ini:

Tabel 2. Hasil analisis sifat fisika,sifat kimia dan kedalaman efektif pada Andisol lahan monokultur dan tumpangsari

\begin{tabular}{lll}
\hline \multirow{2}{*}{ Sifat Fisika dan Kimia } & \multicolumn{2}{c}{ Penggunaan Lahan } \\
\cline { 2 - 3 } Tekstur tanah & $\begin{array}{c}\text { Monokultur } \\
\text { (kentang) /harkat }\end{array}$ & $\begin{array}{l}\text { Tumpangsari } \\
\text { (sawi,wortel)/ harkat }\end{array}$ \\
- pasir $(\%)$ & $\begin{array}{l}\text { Lempung berpasir } \\
\text { - debu }(\%)\end{array}$ & 55 \\
- liat $(\%)$ & 48 & 37 \\
Berat Volume $(\mathrm{gr} / \mathrm{cm} 3)$ & 48 & 8 \\
Berat jenis $(\mathrm{gr} / \mathrm{cm} 3)$ & 4 & 0,142 \\
Porositas $(\%)$ & 0,145 & 0,192 \\
Kedalaman akar(cm) & 0,182 & 73,95 \\
Lengas Kapasitas Lapangan $(\%)$ & 79,7 & 95 \\
pH H20 & 80 & 30,15 \\
pH KCl & 29,36 & 5,3 \\
N total $(\%)$ & 5,5 & 5,1 \\
P tersedia $(p p m)$ & 5,2 & 0,36 \\
K tersedia $(\mathrm{cmol} / \mathrm{kg})$ & 0,40 & 10,42 \\
Bahan organik $(\%)$ & 23,09 & 0,12 \\
C organik $(\%)$ & 0,54 & 5,93 \\
C:N ratio & 5,62 & 3,43 \\
\hline
\end{tabular}


1. Sifat Fisika Tanah

Pada tabel 2 dapat dilihat bahwa Andisol pada lahan monokultur dan tumpangsari mempunyai klas tekstur sama yaitu lempung berpasir, tetapi dari fraksi penyusunnya menunjukkan perkembangan tanah yang berbeda. Hal ini dapat dilihat pada penggunaan lahan monokultur kandungan fraksi pasir $42 \%$, fraksi debu 48\%, fraksi liat $10 \%$, sedangkan pada penggunaan lahan tumpangsari kandungan fraksi pasir $47 \%$, fraksi debu $37 \%$ dan kandungan fraksi liat $16 \%$.

Berdasarkan hasil analisis berat volume dan berat jenis tanah menunjukkan bahwa lahan monokultur mempunyai berat volume atau berat isi $0,145 \mathrm{gr} / \mathrm{cm} 3$ dan berat jenis $0.182 \mathrm{gr} / \mathrm{cm} 3$, sedangkan pada penggunaan lahan tumpangsari berat volume $0,142 \mathrm{gr} / \mathrm{cm} 3$, berat jenis 0,192 $\mathrm{gr} / \mathrm{cm}$, dimana nilai tersebut termasuk rendah. Porositas pada lahan monokultur lebih tinggi dibandingkan dengan lahan tumpangsari yaitu 79,7\%, lahan tumpangsari $73,5 \%$, dimana keduanya termasuk kategori porositas tinggi.

Kedalaman efektif adalah kedalaman tanah yang masih bisa ditembus akar tanaman. Pada lahan monokultur kedalaman efektif $80 \mathrm{~cm}$, sedangkan pada lahan tumpangsari sekitar $95 \mathrm{~cm}$. Lengas kapasitas lapangan pada lahan monokultur dan tumpangsari hampir sama, yaitu 29,36 dan 30,15.

2. Sifat Kimia Tanah

Pada hasil analisa diketahui nilai $\mathrm{pH}$ H2O pada lahan monokultur sebesar 5,5, sedangkan $\mathrm{pH}$ lahan tumpangsari 5,3. Tanah Andosol di Indonesia memiliki kisaran pH yang cukup lebar, yaitu antara 3,4 sampai 6,7 dengan rata-rata 5,4. Tetapi, kisaran $\mathrm{pH}$ antara 4,5 sampai 5,5 merupakan kisaran $\mathrm{pH}$ paling banyak, sedangkan kedua terbanyak adalah pada kisaran $\mathrm{pH}$ antara 5,5 sampai 6,5. Nilai $\mathrm{pH} \mathrm{KCl}$ pada lahan monokultur adalah 5,2 lebih tinggi dibandingkan dengan lahan tumpangsari yakni 5,1.

Nilai C organik pada penggunaan lahan monokultur adalah 3,25, bahan organik 5,62 lebih rendah dibandingkan pada penggunaan lahan tumpangsari yaitu C organik 3,43 dan bahan organik 5,93.

Untuk kandungan $\mathrm{N}$ total pada lahan monokultur lebih tinggi dibandingan pada lahan tumpangsari yaitu 0,40 dan 0,36. Meskipun keduanya termasuk kisaran tinggi. Hal ini dapat dijelaskan bahwa pada praktek pengelolaan pertanian petani banyak memupuk lahannya dengan pupuk organik yang berasal dari tanaman legume yang banyak mengandung $\mathrm{N}$, di samping itu untuk budidaya monokultur yang menggunakan $\mathrm{N}$ adalah satu jenis tanaman saja, sedangkan pada lahan tumpangsari banyak yang menggunakan $\mathrm{N}$ karena pada tumpangsari dalam satu petak terdapat tiga jenis tanaman, meskipun sudah dipupuk dengan kondisi sama seperti pada lahan monokultur.

Kandungan fosfor tersedia pada lahan monokultur lebih tinggi dibandingkan dengan lahan tumpangsari. Ketersediaan fosfor di dalam tanah sangat dipengaruhi oleh $\mathrm{pH}$ tanah. Pada $\mathrm{pH}$ asam fosfor akan difiksasi oleh Al, sedangkan pada $\mathrm{pH}$ basa fosfor akan difiksasi oleh Ca. Berdasarkan hasil analisis reaksi tanah pada lahan monokultur lebih netral dibandingkan pada lahan tumpangsari 
sehingga fosfor tersedia lebih tinggi pada lahan monokultur.

Kandungan kalium pada lahan monokultur lebih tinggi dibandingkan dengan lahan tumpangsari. Ketersediaan kalium sangat dipengaruhi oleh bahan induk dan tingkat perkembangan tanah. Kalium terdapat pada mineral-mineral primer tanah seperti mineral feldspar, mika dan lain-lain, sehingga ditemukan banyak dalam tanah, tetapi sebagian kecil yang dapat dimanfaatkan oleh tanaman yaitu $\mathrm{K}$ yang larut dalam air.

Sifat fisika dan kimia tanah Andisol pada kedua jenis penggunaan lahan, digunakan sebagai indikator menetapkan fungsi-fungsi tanah dalam menentukan Indeks Kualitas Tanah. Tanah dapat berfungsi dengan baik dalam menopang kehidupan organisme yang hidup di dalam dan di atasnya, menunjukkan kualitas tanah yang baik.

3. Indeks Kualitas Tanah

Perhitungan Indeks Kualitas Tanah (Tabel 3) mengacu pada perhitungan IKT dengan metode Minimum Data Set. Menurut Mausbah dan Seybold (1998) dalam Partoyo (2005), yaitu dengan menetapkan fungsi tanah dengan memilih indikator tanah sesuai dengan tingkat lapangan. Tanah mempunyai kualitas baik dapat mendukung kelangsungan hidup organisme di dalam dan di atasnya. Hal ini tidak terlepas dari fungsi tanah sebagai tempat aktivitas biologi, mengatur, dan membagi air serta berfungsi sebagai penyangga (buffer capacity). Fungsi-fungsi tanah dibagi dalam beberapa parameter meliputi sifat fisika, kimia, dan biologi tanah yang sangat mendukung fungsi tanah tersebut.
Tanah sebagai tempat aktivitas biologi terdapat beberapa fungsi indikator yang mendukung aktivitas biologi, yaitu media perakaran, kelengasan dan nutrisi atau keharaan. Penentuan fungsi indikator tanah dengan menggunakan beberapa parameter tanah. Untuk fungsi indikator media perakaran ditentukan dengan parameter kedalaman perakaran dan berat volume (BV).

Fungsi indikator kelengasan ditentukan dengan parameter porositas, jumlah karbon tanah, dan persentase debu dan lempung, sedangkan nutrisi ditentukan dengan parameter $\mathrm{pH}$ tanah, $\mathrm{P}$ tersedia, $\mathrm{K}$ tersedia, $\mathrm{C}$ organik dan $\mathrm{N}$ total.

Tanah berfungsi sebagai tempat pengaturan dan penyaluran air menggunakan parameter persentase debu dan lempung, porositas dan berat volume tanah, sedangkan tanah dapat berfungsi sebagai penyangga yang baik harus didukung oleh parameter persentase debu dan lempung, porositas, $\mathrm{C}$ organic, dan bahan organik tanah.

Data hasil perhitungan indeks kualitas tanah didapatkan dengan mengalikan nilai indeks bobot tanah dengan skor nilai indikator yang diperoleh dari perhitungan koefisien regresi.

Berdasarkan hasil perhitungan didapatkan Indeks Kualitas Tanah untuk lahan monokultur sebesar 0,42 , termasuk kriteria sedang, sedangkan pada lahan tumpangsari 0,38, dengan kriteria rendah. Nilai indeks kualitas tanah berkisar antara 0-1, dan semakin nilai indeks mendekati 1 menunjukkan kualitas semakin baik. 
Tabel 3. Perhitungan Indeks Kualitas Tanah Pada Andisol Lahan Monokultur dan Lahan Tumpangsari (Mausbah and Seybold, 1998)

\begin{tabular}{|c|c|c|c|c|c|c|c|c|c|c|c|c|}
\hline \multirow[t]{3}{*}{ Fungsi Tanah } & \multirow[t]{3}{*}{ Bobot I } & \multirow[t]{3}{*}{ Indikator Tanah } & \multirow{3}{*}{$\begin{array}{c}\text { Bobot } \\
\text { II }\end{array}$} & \multirow{3}{*}{$\begin{array}{l}\text { Bobot } \\
\text { III }\end{array}$} & \multirow{3}{*}{$\begin{array}{l}\text { Indeks } \\
\text { Bobot }\end{array}$} & \multicolumn{4}{|c|}{ Nilai Indikator Tanah } & \multicolumn{2}{|c|}{ Indeks Kualitas Tanah } & \multirow{3}{*}{$\begin{array}{l}\text { Rata- } \\
\text { rata }\end{array}$} \\
\hline & & & & & & \multicolumn{2}{|c|}{ Monokultur } & \multicolumn{2}{|c|}{ Tumpangsari } & \multirow[t]{2}{*}{ Monokultur } & \multirow{2}{*}{ Tumpangsari } & \\
\hline & & & & & & Nilai & Skor & Nilai & Skor & & & \\
\hline \multirow{13}{*}{$\begin{array}{l}\text { Melestarikan aktivitas } \\
\text { biologi }\end{array}$} & \multirow{13}{*}{0,4} & Medium Perakaran & 0,30 & & & & & & & & & \\
\hline & & Jeluk Perakaran & & 0,6 & 0,072 & 80 & 0,54 & 95 & 0,78 & 0,039 & 0,056 & 0,048 \\
\hline & & $\begin{array}{l}\text { Berat } \quad \text { Volume } \\
\mathrm{g} / \mathrm{cm}\end{array}$ & & 0,4 & 0,048 & 0,145 & 0,75 & 0,142 & 0,50 & 0,036 & 0,024 & \\
\hline & & Kelengasan & 0,30 & & & & & & & & & \\
\hline & & Porositas \% & & 0,2 & 0,024 & 79,7 & 0,13 & 73,95 & 0,6 & 0,003 & 0,014 & 0,009 \\
\hline & & C organik \% & & 0,4 & 0,048 & 3,25 & 0,75 & 3,43 & 0,75 & 0,036 & 0,036 & 0,036 \\
\hline & & Debu + Lempung & & 0,4 & 0,048 & 52 & 0,25 & 45 & 0,07 & 0,012 & 0,003 & 0,008 \\
\hline & & Keharaan & 0,30 & & & & & & & & & \\
\hline & & $\mathrm{pH}$ & & 0,1 & 0,012 & 5,5 & 0,75 & 5,3 & 0,75 & 0,009 & 0,009 & 0,009 \\
\hline & & P tsd ppm & & 0,2 & 0,024 & 23,09 & 1 & 10,42 & 0,5 & 0,024 & 0,012 & 0,018 \\
\hline & & $\mathrm{K}$ tsd me/100 g & & 0,2 & 0,024 & 0,54 & 0,75 & 0,12 & 0,25 & 0,018 & 0,006 & 0,012 \\
\hline & & C-organik \% & & 0,3 & 0,036 & 3,25 & 0,75 & 3,43 & 0,75 & 0,027 & 0,027 & 0,027 \\
\hline & & $\mathrm{N}$ tot $\%$ & & 0,2 & 0,024 & 0,40 & 1 & 0,36 & 1 & 0,024 & 0,024 & 0,024 \\
\hline \multirow[t]{3}{*}{$\begin{array}{l}\text { Pengaturan dan } \\
\text { penyaluran air }\end{array}$} & \multirow[t]{3}{*}{0,3} & $\begin{array}{l}\text { Debu + Lempung } \\
\%\end{array}$ & 0,60 & & 0,180 & 52 & 0,25 & 45 & 0,07 & 0,045 & 0,013 & 0,029 \\
\hline & & Porositas \% & 0,20 & & 0,060 & 79,7 & 0,13 & 73,95 & 0,60 & 0,008 & 0,036 & 0,022 \\
\hline & & $\begin{array}{l}\text { Berat } \quad \text { Volume } \\
\mathrm{g} / \mathrm{cm} 3\end{array}$ & 0,20 & & 0,060 & 0,145 & 0,75 & 0,142 & 0,75 & 0,045 & 0,045 & 0,045 \\
\hline \multirow[t]{5}{*}{ Filter dan buffering } & \multirow[t]{5}{*}{0,3} & $\begin{array}{l}\text { Debu + lempung } \\
\%\end{array}$ & 0,60 & & 0,180 & 52 & 0,25 & 45 & 0,07 & 0,045 & 0,013 & 0,029 \\
\hline & & Porositas \% & 0,10 & & 0,030 & 79,7 & 0,13 & 73,95 & 0,60 & 0,004 & 0,018 & 0,011 \\
\hline & & $\begin{array}{l}\text { Proses } \\
\text { Mikrobiologis }\end{array}$ & 0,30 & & & & & & & & & \\
\hline & & C-Organik \% & & 0,5 & 0,045 & 3,25 & 0,75 & 3,43 & 0,75 & 0,034 & 0,034 & 0,034 \\
\hline & & Bahan Organik \% & & 0,5 & 0,045 & 5,62 & 0,21 & 5,93 & 0,18 & 0,009 & 0,008 & 0,009 \\
\hline Total & & & & & 1,0 & & & & & 0,42 & 0,38 & 0,37 \\
\hline
\end{tabular}


Juarti. Analisis Indeks Kualitas Tanah Andisol Pada Berbagai Penggunaan Lahan di Desa Sumber Brantas Kota Batu

Tabel 4. Kriteria kualitas tanah berdasarkan nilai Indeks Kualitas Tanah (IKT)

\begin{tabular}{ccc}
\hline No. & Kelas Nilai IKT & Kriteria Kualitas Tanah \\
\hline 1. & $0,80-1,00$ & Sangat baik \\
2. & $0,60-0,79$ & Baik \\
3. & $0,40-0,59$ & Sedang \\
$\mathbf{4 .}$ & $0,20-0,39$ & Rendah \\
$\mathbf{5 .}$ & $0,00-0,19$ & Sangat rendah \\
\hline
\end{tabular}

Sumber: Partoyo (2005)

\section{PEMBAHASAN}

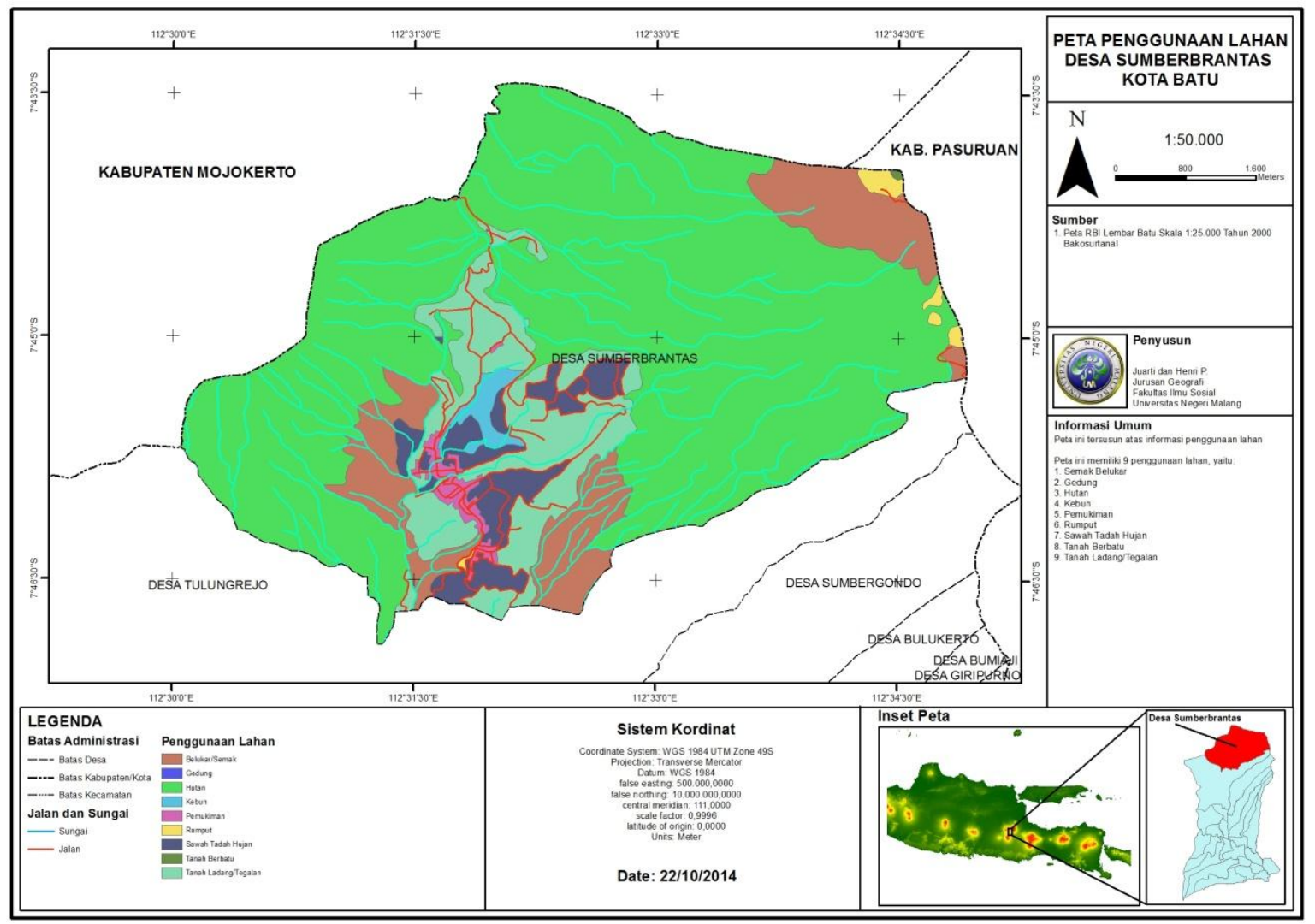

Gambar 2. Peta Penggunaan lahan

Berdasarkan hasil analisa tekstur tanah Andisol pada penggunaan lahan monokultur maupun tumpangsari mempunyai kelas sama yakni lempung berpasir. Tekstur pada penggunaan lahan tumpangsari lebih berkembang dibandingkan dengan monokultur. Hal ini disebabkan karena pengaruh bahan or- ganik. Pada proses dekomposisi bahan organik menghasilkan asam2 organik yang merupakan pelarut efektif bagi batuan dan mineral-mineral primer (pasir dan debu) sehingga lebih mudah pecah menjadi ukuran yang lebih kecil yakni lempung. Selain itu, kerapatan akar lebih tinggi pada tumpangsari akan memper- 
cepat penghancuran secara fisika sehingga fraksi yang lebih halus akan cepat terbentuk.

Tekstur tanah sangat menentukan kecepatan infiltrasi dan kemampuan tanah menahan air. Tanah yang didominasi fraksi pasir mempunyai infiltrasi tinggi, gampang meloloskan air sehingga kemampuan mengikat air rendah. Kandungan fraksi liat sedikit menyebabkan tanah mempunyai kemantapan agregat rendah sehingga sering kehilangan unsur hara akibat pencucian maupun bahaya erosi. Tekstur tanah akan mempengaruhi tata udara di dalam tanah dan mempengaruhi kehidupan mikroorganisme maupun makroorganisme di dalam tanah.

Berat isi tanah Andosol di Indonesia sangat bervariasi, yaitu berkisar dari 0,37 sampai 0,90 gcm-3. Rendahnya berat isi tanah Andosol ini tidak terlepas dari pengaruh kandungan mineral amorf yang dominan. Dalam tanah Andisol yang didominasi oleh mineral amorf, jumlah pori mikro cukup banyak terutama pori intra dan inter partikel dari alofan. Berat volume akan mempengaruhi ruang pori tanah, semakin rendah nilai berat volume maka ruang pori akan semakin tinggi.

Hasil perhitungan persentase pori tanah menunjukkan bahwa porositas penggunaan lahan monokultur lebih besar dibandingkan dengan penggunaan lahan tumpangsari. Ruang pori adalah bagian yang diduduki oleh udara dan air. Jumlah ruang pori sebagian besar ditentukan oleh susunan butir-butir padat. Pada penggunaan lahan monokultur susunan butir-butir relatif lebih renggang dibandingkan dengan penggunaan lahan tumpang sari karena kandungan pasirnya lebih sedikit sehinga porositasnya lebih besar, dengan kandungan pasir yang lebih besar pada penggunaan lahan tumpangsari menyebabkan susunan butirbutir menjadi padat sehingga porositasnya menjadi lebih rendah. Semakin besar nilai porositas menyebabkan daya simpan air secara maksimum akan besar pula. Berdasarkan klasifikasi kedua penggunaan lahan mempunyai porositas yang tinggi.

Berdasarkan hasil analisa $\mathrm{pH}$ kedua penggunaan lahan monokutur dan tumpangsari adalah 5,5 dan 5,3. Banyaknya contoh pada kisaran $\mathrm{pH} 4,5$ sampai 5,5 dan 5,5 sampai 6,5 menunjukkan bahwa tanah Andosol di Indonesia didominasi oleh mineral-mineral liat amorf. Tanah Andosol ini berasal dari daerah yang mempunyai curah hujan tinggi dengan bahan induk bersifat andesitik, atau andesitik-basaltik. Pada penggunaan lahan tumpangsari nilai $\mathrm{pH}$ lebih kecil karena terjadi pencucian lebih tinggi. Fraksi pasir yang lebih tinggi pada tumpangsari menyebabkan kemampuan tanah memegang unsur hara dan kationkation basa lebih kecil sehingga mudah hilang terbawa air perkolasi dan menyebabkan penurunan nilai $\mathrm{pH}$.

Nilai $\mathrm{pH} \mathrm{KCl}$ pada penggunaan lahan monokultur dan tumpangsari adalah 5,2 dan 5,1. Hal ini menunjukkan bahwa lahan tumpangsari mempunyai total ion $\mathrm{H}+$ lebih tinggi. $\mathrm{pH} \mathrm{KCl} \mathrm{lebih} \mathrm{rendah} \mathrm{dari}$ pH H20 pada kedua jenis penggunaan lahan,sehingga $\Delta \mathrm{pH}$ antara $\mathrm{pH} \mathrm{KCl}$ dan $\mathrm{pH} \mathrm{H} 2 \mathrm{O}$ bernilai negatif. Selisih antara $\mathrm{pH} \mathrm{KCl}$ dan $\mathrm{pH} \mathrm{H} 2 \mathrm{O}$ atau disebut juga $\Delta \mathrm{pH}$. Nilai $\Delta \mathrm{pH}$ merupakan gambaran suatu tanah bermuatan variabel. Suatu tanah bermuatan variabel jika 
memiliki nilai $\Delta \mathrm{pH}$ antara $-0,5 \mathrm{~s} / \mathrm{d} 0,0$. Nilai $\Delta \mathrm{pH}$ negatif menunjukkan tanah didominasi muatan negatif. Reaksi tanah $(\mathrm{pH})$ tidak hanya menunjukkan sifat kemasaman atau kebasaan suatu tanah, melainkan juga berkaitan dengan sifat kimia tanah lainya, misalnya ketersediaan unsur hara fosfat dan kation-kation basa yang lain.

Bahan organik dan C-organik tumpangsari lebih tinggi dibandingkan dengan lahan monokultur hal ini disebabkan karena pada tipe penggunaan lahan ini mempunyai jenis tanaman beragam, pengelolaan tanahnya tidak intensif dan dipupuk dengan pupuk kandang. Penggunaan lahan tumpangsari merupakan tipe penggunaan lahan yang baik untuk mempertahankan kandungan $\mathrm{C}$ organik tetap tinggi dan aktivitas biologi tanahnyapun tertinggi pada tipe penggunaan lahan ini.

Secara umum kandungan bahan organik pada tanah Andisolrelatif tinggi, tetapi bahan organik dan $\mathrm{C}$ organik pada lahan tumpangsari lebih tinggi dibandingkan dengan lahan monokultur. Hal ini disebabkan pada lahan tumpangsari dipupuk dengan bahan organik yang berasal dari kotoran hewan, di samping itu sisa-sisa hasil tanaman dimasukkan sebagai pupuk hijau, sedangkan pada lahan monokultur bahan organik dan $\mathrm{C}$ organik lebih rendah disebabkan oleh sistem pengolahan tanah yang tidak tepat akan menguras bahan organik. Pengolahan tanah yang intensif akan menyebabkan kandungan bahan organik semakin rendah dengan meningkatnya oksidasi bahan organik oleh mikroorganisme tanah. Pengolahan tanah yang terus-menerus akan mempercepat dekomposisi seresah dan oksidasi bahan organik, sehingga mengurangi kandungan bahan organik dan kestabilan agregat tanah.

Berdasarkan hasil analisis ketiga unsur makro N, P, K pada lahan monokultur lebih tinggi dibandingkan dengan lahan tumpangsari. Hal ini disebabkan pada lahan monokultur hanya satu jenis tanaman sehingga unsur hara yang tersedia tidak banyak terserap. Pada lahan tumpangsari ketiga unsur hara makro tersebut akan banyak terserap oleh tanaman disamping itu penanaman biasanya dilakukan pada lereng yang miring sehingga banyak tercuci, di samping itu karakter dari Andisol yang berada pada iklim udic,dimana tanah tidak mengalami kekeringan selama 90 hari dan terjadi pencucian sepanjang tahun.

Berdasarkan hasil perhitungan didapatkan Indeks Kualitas Tanah untuk lahan monokultur sebesar 0,42 , termasuk kriteria sedang, sedangkan pada lahan tumpangsari 0,38 , dengan kriteria rendah. Tanah Andisol pada penggunaan monokultur dengan tanaman kentang menunjukkan kualitas tanah sedang, sedangkan pada penggunaan lahan tumpangsari dengan tanaman sawi dan wortel menunjukkan kualitas rendah.

Penanaman monokultur adalah menanam satu jenis tanaman pada lahan dan waktu yang sama. Kelebihan sistem ini yaitu teknis budidayanya relatif mudah karena tanaman yang ditanam hanya satu jenis, tetapi disisi lain kelemahan sistem ini adalah berperan memerosotkan kualitas tanah. Jenis tanaman sama yang ditanaman secara terus menerus tanpa adanya rotasi tanaman menyebabkan unsur hara yang sama akan diserap tanaman 
dalam jangka waktu lama. Kondisi ini diperparah dengan tidak adanya tindakan konservasi yang memadai. Sebagian besar di desa Sumber brantas tanaman kentang ditanaman secara monoklutur dan menurut arah lereng, sehingga pada saat hujan turun erosi yang terjadi akan semakin besar. Hal ini disebabkan kondisi lahan pertanian yang terletak pada lereng miring. Erosi yang terjadi akan membawa lapisan oleh tanah yang banyak mengandung unsur hara, di samping itu pemupukan yang melebihi dosis akan banyak unsur hara yang terbuang sebelum dimanfaatkan tanaman. Lahan yang ditanami sayur-sayuran di Desa Sumberbrantas sebagian besar berada pada lerengmiring. Hal ini diperparah dengan tanpa adanya tindakan konservasi yang baik sehingga sering terjadi erosi yang membawa serta unsur hara pada lapisan olah. Di samping itu, tekstur tanahnya banyak didominasi fraksi debu yang mudah tererosi.

Pada pola tanam tumpangsari indeks kualitas tanah termasuk kategori tengah. Tumpangsari adalah menanam lebih dari satu jenis tanaman pada lahan sama dalam waktu bersamaan. Keuntungan pola tanam tumpangsari adalah menghasilkan panen beragam dan dapat menambah kesuburan.Tetapi, yang terjadi di desa Sumberbrantas penggunaan lahan tumpang sari indeks kualitas tanah justru rendah. Tumpang sari selain menguntungkan secara produksi karena mendapatkan hasil panen beragam, tetapi juga mempunyai kelemahan yakni terjadi persaingan unsur hara antara tanaman, apabila pemilihan jenis tanaman tidak sama. Kombinasi yang baik akan tercapai apabila tanaman berakar dalam ditanam dengan tanaman berakar pendek akan membantu menggemburkan tanah. Pada kasus ini tanaman sawi ditanam bersamaan dengan tanaman wortel yang samasama mempunyai akar serabut dan terjadi persaingan unsur hara maka makin lama indeks kualitas tanah akan semakin rendah. Kondisi ini diperparah dengan pemupukan dengan pupuk anorganik dalam jangka waktu lama akan merusak sifat fisik tanah. Karakteristik Andisol sendiri adalah didominasi tekstur debu dengan berat volume ringan sehingga rentan sekali terhadap bahaya erosi apabila tanpa disertai tindakan konservasi yang baik

\section{KESIMPULAN}

Berdasarkan hasil perhitungan dapat disimpulkan Indeks Kualitas Tanah (IKT) lahan monokultur sebesar 0,42 termasuk kriteria sedang, lahan tumpangsari Indeks Kualitas Tanah sebesar 0,38 termasuk kriteria rendah.

\section{DAFTAR PUSTAKA}

Anonim. 2014. Produksi Sayur Sumber Brantas Drop. Jawa Pos Oktober 2014.

Arifin, Zaenal. 2011. Analisis Indeks Kualitas Tanah Entisol pada Berbagai Penggunaan Lahan yang Berbeda. Agroteksos Vol. 21 No. 1 April 2011. Fakultas Pertanian Unram.

Darmawijaya, M.I.1997. Klasifikasi Tanah. Yogjakarta: UGM Press.

Ditzler,C.A. and Tugel, A. J.2002. Soil Quality Field Tools: Experiences of USDA-NRCS Soil Quality Institute. Agron. J.94

Handayanto, Handayanto. 1987. DasarDasar Genesa dan klasifikasi Tanah. Communications Soil Science Unibrwaw. 
Juarti. Analisis Indeks Kualitas Tanah Andisol Pada Berbagai Penggunaan Lahan di Desa Sumber Brantas Kota Batu

Hardjowigeno, Sarwono. 1987. Klasifikasi tanah dan Pedogenesis. Jakarta: Akapress..

Hardjowigeno, Sarwono. 2003. Ilmu Tanah. Jakarta: Akademia Pressindo.

Karlen, D. Land. And Mausbach, M.J.2001. Soil Quality Assesment, (online), (www.nstl.gov)

Larson, W.E and Pierce, F. J.1994. Conservation and Enhancement of Soil Quality. In: The Soil Quality Institude (Ed). The Soil Quality Consept. USA: USDA Natural Resources Conservation Servis.

Mausbach, M. J and C. A . Seybold. 1998. Assesment of Soil Quality. In Soil Soil Quality and Agriculture Sustainability. Michigan: Ann Arbor Press.

Munir, M.1996. Tanah-Tanah Utama di Indonesia. Jakarta: Pustaka Jaya.

Partoyo. 2005. Analisis Indeks Kualitas Tanah Pada Tanah Pasir Pantai Samas Yogjakarta. Jurnal Ilmu Pertanian, Vol. 12 No.2, Jurusan Tanah UPN Yogjakarta.

Primadani, Prasti. 2008. Pemetaan Kualitas Tanah Pada Beberapa Penggunaan Lahan Di Kecamatan Jatipuro Kabupaten Karanganyar.
Surakarta: Fakultas Pertanian Universitas Sebelas Maret Surakarta

Purwanto. 2002. Biota Tanah Sebagai Indikator kualitas Tanah. Malang: Universitas Brawijaya.

Sanchez, P. A. 1992. Properties and Management of Soil in the Tropics. Amerika: John Wiley and Sons.

Sartohadi, Junun, dkk., 2012. Pengantar Geografi Tanah. Yogjakarta: Penerbit Pustaka Pelajar.

Soil Quality Institute. 1999. Soil Quality Test Kit Guide. Washington: United States Department of Agriculture.

Suripin. 2004. Pelestarian Sumber Daya Tanah dan Air. Yogjakarta: Andi.

Suriadi, Ahmad dan Nazam. 2005. Penilaian kualitas tanah Berdasar Kandungan Bahan Organik di Kabupaten Bima, (online), (www.litbang.deptan.go.id)

Waluyaningsih, Sri Rahayu. 2008. Studi Analisis Kualitas Tanah Pada Beberapa Penggunaan Lahan Dan Hubungannya Dengan Tingkat Erosi Di Sub Das Keduang Kecamatan Jatisrono Wonogiri. Surakarta: Program Studi Ilmu LingkunganProgram Pascasarjana Universitas Sebelas Maret Surakarta. 